\title{
Targeting cell migration and the endoplasmic reticulum stress response with calmodulin antagonists: a clinically tested small molecule phenocopy of SEC62 gene silencing in human tumor cells
}

Maximilian Linxweiler ${ }^{1 \dagger}$, Stefan Schorr ${ }^{1 \dagger}$, Nico Schäuble ${ }^{1}$, Martin Jung ${ }^{1}$, Johannes Linxweiler ${ }^{1}$, Frank Langer ${ }^{2}$, Hans-Joachim Schäfers ${ }^{2}$, Adolfo Cavalié ${ }^{3}$, Richard Zimmermann ${ }^{1}$ and Markus Greiner ${ }^{1 *}$

\begin{abstract}
Background: Tumor cells benefit from their ability to avoid apoptosis and invade other tissues. The endoplasmic reticulum (ER) membrane protein Sec62 is a key player in these processes. Sec62 is essential for cell migration and protects tumor cells against thapsigargin-induced ER stress, which are both linked to cytosolic $\mathrm{Ca}^{2+}$. SEC62 silencing leads to elevated cytosolic $\mathrm{Ca}^{2+}$ and increased $\mathrm{ER} \mathrm{Ca}^{2+}$ leakage after thapsigargin treatment. Sec62 protein levels are significantly increased in different tumors, including prostate, lung and thyroid cancer.

Methods: In lung cancer, the influence of Sec62 protein levels on patient survival was analyzed using the Kaplan-Meier method and log-rank test. To elucidate the underlying pathophysiological functions of Sec62, $\mathrm{Ca}^{2+}$ imaging techniques, real-time cell analysis and cell migration assays were performed. The effects of treatment with the calmodulin antagonists, trifluoperazine (TFP) and ophiobolin A, on cellular $\mathrm{Ca}^{2+}$ homeostasis, cell growth and cell migration were compared with the effects of siRNA-mediated Sec62 depletion or the expression of a mutated SEC62 variant in vitro. Using Biacore analysis we examined the $\mathrm{Ca}^{2+}$-sensitive interaction of Sec62 with the Sec61 complex.
\end{abstract}

Results: Sec62 overproduction significantly correlated with reduced patient survival. Therefore, Sec62 is not only a predictive marker for this type of tumor, but also an interesting therapeutic target. The present study suggests a regulatory function for Sec62 in the major $\mathrm{Ca}^{2+}$ leakage channel in the $\mathrm{ER}$, Sec61, by a direct and $\mathrm{Ca}^{2+}$-sensitive interaction. A Ca ${ }^{2+}$-binding motif in Sec62 is essential for its molecular function. Treatment of cells with calmodulin antagonists mimicked Sec62 depletion by inhibiting cell migration and rendering the cells sensitive to thapsigargin treatment.

Conclusions: Targeting tumors that overproduce Sec62 with calmodulin antagonists in combination with targeted thapsigargin analogues may offer novel personalized therapeutic options.

Keywords: Endoplasmic reticulum (ER) stress, Cell migration, $\mathrm{Ca}^{2+}$ homeostasis, Calmodulin antagonists, Sec62

\footnotetext{
* Correspondence: m.greiner@uks.eu

${ }^{\dagger}$ Equal contributors

'Department of Medical Biochemistry and Molecular Biology, Saarland

University, Homburg, Saarland, Germany

Full list of author information is available at the end of the article
} 


\section{Background}

Cancer is one of the most common deadly diseases [1], and the proportion of patients dying because of malignant disease is increasing every year [2]. Lung cancer is of particular concern with a five-year survival rate below $20 \%$ [3]. Therapeutic opportunities are scarce for patients suffering from squamous cell carcinoma (SCC) of the lung [4]. We have recently reported SEC62 as a new candidate oncogene, as it is significantly overexpressed with elevated protein levels in SCC [5].

Sec62 is an essential protein in yeast and part of the Sec62/Sec63 sub-complex of the SEC complex, acting as a docking site for posttranslational protein transport [6]. Studies in mammals have shown that Sec62 is associated with the heterotrimeric Sec61 complex and Sec63 [7,8], and that it participates in the targeting and translocation of small pre-secretory proteins to the endoplasmic reticulum (ER) $[9,10]$. Mammalian Sec62 can also interact with the ribosome, thereby regulating translation [11]. Elevated Sec62 protein levels are functionally linked to increased cell migration capability [12] and reduced sensitivity to thapsigargin-induced ER stress [13], both of which are tightly regulated by the cytosolic $\mathrm{Ca}^{2+}$ concentration [14-16]. Previously, we have shown that reduced Sec62 protein levels lead to an at least two-fold increase in basal cytosolic $\mathrm{Ca}^{2+}$ and a much greater increase in cytosolic $\mathrm{Ca}^{2+}$ concentration in response to thapsigargin treatment (i.e., increased ER Ca ${ }^{2+}$ leakage) [13]. These results demonstrate a significant influence of Sec62 on ER Ca ${ }^{2+}$ homeostasis, making Sec62 a promising target for new therapeutic approaches. Regulation of cytosolic $\mathrm{Ca}^{2+}$ levels by targeting this protein may induce anti-metastatic and anti-proliferative effects.

In the present study, we used small molecule inhibitors of the $\mathrm{Ca}^{2+}$-binding protein, calmodulin, to mimic the phenotypes previously observed after SEC62 silencing. This approach provided new insight into the physiological function of Sec62 and may lead to a new therapeutic strategy for personalized cancer therapy.

\section{Methods}

\section{Cell culture and tissue samples}

PC3 (DSMZ no. ACC 465), HeLa (DSMZ no. ACC 57), A549 (DSMZ no. ACC 107), BC01 (kindly provided by G. Unteregger, Saarland University Hospital, Department of Urology and Pediactric Urology), BHT 101 (DSMZ no. ACC 279), ML1 (DSMZ no. ACC 464) and HEK293 (DSMZ no. ACC 305) cells were cultured at $37^{\circ} \mathrm{C}$ in DMEM medium (Gibco Invitrogen, Karlsruhe, Germany) containing 10\% fetal bovine serum (FBS; Biochrom, Berlin, Germany) and 1\% penicillin/streptomycin (PAA, Pasching, Austria) in a humidified environment with 5\% $\mathrm{CO}_{2}$. H1299 cells (ATCC no. CRL-5803D) were cultured in RPMI1640 medium (PAA) containing the same supplements. We used stably transfected HEK293 cells expressing plasmid-encoded wild-type SEC62 (pSEC62-IRES-GPF) or an empty control plasmid (pIRES-GPF) [5]. A plasmid encoding SEC62 with a D308A point mutation (pSEC62 ${ }_{D 308 A}$-IRES-GPF) was generated using the QuikChange Site-Directed Mutagenesis Kit (Stratagene, La Jolla, CA, USA) according to the manufacturer's instructions. The plasmid was sequenced to confirm the point mutation. A stably transfected cell line expressing this mutant gene was generated by transfecting $2.4 \times 10^{5}$ HEK293 cells in a 6-well plate using FuGeneHD Reagent (QIAGEN, Hilden, Germany) according to the manufacturer's instructions. After $72 \mathrm{~h}$, the medium was replaced with normal culture medium containing 1\% G418 and the cells were cultured until selection was achieved. After harvesting, the cells were diluted to a density of 1 cell per $100 \mu \mathrm{l}$, and $100 \mu \mathrm{l}$ were seeded in each well of a 96-well plate in medium containing 1\% G418. Clones originating from a single cell were selected and analyzed for Sec62 content. All experiments using stably transfected cell lines were performed in normal growth medium containing 1\% G418. Stably transfected HEK293 cells were used for migration assays, as transient transfection or treatment with FuGeneHD transfection reagent strongly inhibits cell migration.

We analyzed Sec62 levels in cancerous and tumor-free lung tissue from 70 non-small cell lung cancer (NSCLC) patients with pathologically confirmed adenocarcinoma (AC) or squamous cell carcinoma (SCC) using western blot with $\beta$-actin as a loading control. We calculated the relative elevation in the Sec62 protein content $(\mathrm{rSec} 62=$ $\left[\right.$ Sec62 $2_{\text {tumor }} / \mathrm{b}$-actin tumor $\left._{\text {tur }}\right] /\left[\right.$ Sec62 $2_{\text {tumor-free }} / \mathrm{b}$-actin tumor-free $\left.]\right)$ in the tumor [5]. All patients $(n=70)$ and the subgroups of AC $(n=35)$ and SCC $(n=35)$ patients were divided into two groups based on the median rSec62 value, and survival analyses were performed using the Kaplan-Meier method and the log-rank test. Only samples from patients who gave signed informed consent were used. All samples were received for therapeutic or diagnostic purpose and anonymized. Therefore, according to the guidelines of the local ethics board ("Ethikkommision der Ärztekammer des Saarlandes") and the statement of the national ethics committee (nationaler Ethikrat (Hrsg.): Biobanken für die Forschung. Stellungnahme. Berlin 2004 [http://www.ethikrat. org/dateien/pdf/NER_Stellungnahme_Biobanken.pdf]) they can be used without specific approval by an ethics board.

\section{Western blot}

Protein in lysates from $2 \times 10^{5}$ cultured cells was quantified by western blot analysis. We used an affinity-purified polyclonal rabbit anti-peptide antibody directed against the C-terminus of human Sec62, a polyclonal rabbit anti-BiP antibody, a polyclonal rabbit anti-peptide antibody directed against the C-terminus of human Sec61 $\alpha$, and a monoclonal murine anti- $\beta$-actin antibody (Sigma Aldrich, Taufkirchen, Germany, A5441-.5ML). The primary 
antibodies were visualized using an $\mathrm{ECL}^{\mathrm{TM}}$ Plex goat antirabbit IgG-Cy5 or ECL ${ }^{\mathrm{TM}}$ Plex goat anti-mouse IgG-Cy3 conjugate (GE Healthcare, Munich, Germany), and the Typhoon-Trio imaging system (GE Healthcare) in combination with Image Quant TL software 7.0 (GE Healthcare). We determined the ratio of Sec62, Sec61 $\alpha$ and BiP relative to $\beta$-actin.

\section{Silencing of gene expression by siRNA}

For gene silencing, $5.4 \times 10^{5}$ cells were seeded in $6-\mathrm{cm}$ dishes containing normal culture medium. The cells were transfected with SEC62-UTR siRNA (CGUAAA GUGUAUUCUGUACtt; Ambion, Life Technologies, Carlsbad, CA, USA), SEC62 siRNA (GGCUGUGGCCAAG UAUCUUtt; Ambion), SEC61A1 siRNA (GGAAUUUGCC UGCUAAUCAtt, QIAGEN, Hilden, Germany), or control siRNA (AllStars Neg. Control siRNA; QIAGEN) using HiPerFect Reagent (QIAGEN) according to the manufacturer's instructions. After $24 \mathrm{~h}$, the medium was changed and the cells were transfected a second time. Silencing efficiency was evaluated by western blot analysis. The maximum silencing effect was seen 72 h (SEC62 siRNAs) or $96 \mathrm{~h}$ (SEC61A1 siRNA) after the first transfection.

\section{Real-time cell proliferation analysis}

The xCELLigence SP system (Roche Diagnostics GmbH, Mannheim, Germany) was used for real-time analysis of cell proliferation. In this system, $1.0 \times 10^{4}$ or $2.0 \times 10^{4}$ stably transfected HEK293 cells, untreated HEK293, PC3 or HeLa cells, or PC3 cells pretreated with siRNA in 6$\mathrm{cm}$ dishes were seeded into a 96-well e-plate (Roche Diagnostics $\mathrm{GmbH}$ ) according to the manufacturer's instructions. Cells pretreated with siRNA were seeded $24 \mathrm{~h}$ after the second transfection. When cells were treated with thapsigargin, TFP or ophiobolin A, the treatment was performed at least $4 \mathrm{~h}$ after seeding the plates. Cell proliferation was monitored for 53-96 h and the data was evaluated with RTCA 1.2 software (Roche Diagnostics $\mathrm{GmbH}$ ). Thapsigargin was used at concentrations of 6 or $10 \mathrm{nM}$, because these concentrations did not affect cell growth. This is in contrast to the live-cell calcium imaging experiments, where $1 \mu \mathrm{M}$ thapsigargin was used to visualize short-term calcium effects monitored only over a time span of up to $1200 \mathrm{~s}$.

\section{Peptide spot binding assay}

Thirteen peptides spanning the N-terminus of the human Sec61 $\alpha$ protein were synthesized on cellulose membranes via a C-terminal attachment as described previously $[17,18]$. The peptides consisted of 12 amino acid residues with an overlap of 10 residues and were incubated in binding buffer (30 mM Tris- $\mathrm{HCl}, \mathrm{pH} 7.4,170 \mathrm{mM} \mathrm{NaCl}$, $6.4 \mathrm{mM} \mathrm{KCl}, 5 \%$ sucrose, $0.05 \%$ Tween 20) with Sec62C-6His $(1 \mu \mathrm{M})$, which was purified from Escherichia coli as described previously [11]. To detect bound protein, the membranes were washed twice with binding buffer, incubated with anti-His-POD-coupled antibody (1:1000, QIAGEN), washed twice with binding buffer again, incubated with ECL (GE Healthcare) and visualized using a lumi-imaging system (Roche Diagnostics $\mathrm{GmbH}$ ).

\section{Surface plasmon resonance spectroscopy}

Surface plasmon resonance (SPR) spectroscopy was performed in a BIAlite upgrade system (Biacore, Freiburg, Gerrmany). Peptides representing the N-terminus of Sec61 (AIKFLEVIKPFC) or the N-terminus of TRAM (VLSHEFELQNGADC) were immobilized in the measuring cell or control cell, respectively, on a CM5 sensor chip using ligand-thiol-coupling according to the manufacturer's protocol. Measurements were performed at a flow rate of $10 \mu \mathrm{l} / \mathrm{min}$ in a $\mathrm{Ca}^{2+}$-free buffer containing $10 \mathrm{mM}$ HEPES-KOH, pH 7.4, $150 \mathrm{mM} \mathrm{NaCl}, 2 \mathrm{mM}$ $\mathrm{MgCl}, 6.4 \mathrm{mM} \mathrm{KCl}$ and $0.005 \%$ surfactant. For interaction analysis, E. coli-purified Sec62-C-6His $(1 \mu \mathrm{M})$ [11] in buffer minus $\mathrm{Ca}^{2+}$ or in the same buffer containing $2 \mathrm{mM} \mathrm{Ca}^{2+}$, or the $\mathrm{Ca}^{2+}$-containing buffer alone was passed over the chip. Response units are shown as the difference between the measuring and control cells. The analysis was carried out using BIA evaluation software version 3.1 (Biacore) with 1:1 binding models and mass transfer.

\section{Migration potential analysis}

Migration was tested using the BD Falcon FluoroBlok system (BD, Franklin Lakes, NJ, USA) in 24-well inserts. A total of $2.5 \times 10^{4}$ stably transfected HEK293 cells, or untreated PC3 or HeLa cells were loaded in normal medium containing $0.5 \%$ FBS. When DMSO, TFP or ophiobolin A was used, the drugs were added to the top and bottom chambers at various concentrations. The inserts were placed in medium with $10 \%$ FBS as a chemoattractant. After $72 \mathrm{~h}$, the cells were fixed with methanol and stained with DAPI, and migrating cells were analyzed on the back of the membrane using fluorescence microscopy.

\section{Live-cell calcium imaging}

For live-cell $\mathrm{Ca}^{2+}$ imaging, HeLa cells were loaded with $4 \mu$ M FURA-2 AM (Molecular Probes, Eugene, OR, USA) in DMEM for $45 \mathrm{~min}$ at room temperature as described previously $[19,20]$. Two washes were performed with a $\mathrm{Ca}^{2+}$-free buffer (140 mM NaCl, $5 \mathrm{mM} \mathrm{KCl,} 1 \mathrm{mM} \mathrm{MgCl}_{2}$, $0.5 \mathrm{mM}$ EGTA and $10 \mathrm{mM}$ glucose in $10 \mathrm{mM}$ HEPES$\mathrm{KOH}, \mathrm{pH}$ 7.35) and the experiments were carried out in the same solution. A ratiometric measurement was performed for $3 \mathrm{~min}$ to determine the initial cytosolic $\left[\mathrm{Ca}^{2+}\right]$. The measurement was continued after the addition of $1 \mu \mathrm{M}$ thapsigargin or - to measure store operated calcium entry (SOCE) - $2.5 \mathrm{mM} \mathrm{Ca}^{2+}$. Cells pretreated as described in the text were compared with respect to 
the initial cytosolic $\left[\mathrm{Ca}^{2+}\right]$ and thapsigargin-induced changes in cytosolic $\left[\mathrm{Ca}^{2+}\right]$. Data were collected by an iMIC microscope and polychromator V (Till Photonics, Graefelfing, Germany) by alternating excitation between 340 and $380 \mathrm{~nm}$, and measuring the emitted fluorescence at $510 \mathrm{~nm}$ (dichroic, DCLP410; emitter filter LP470; Till Photonics). Images containing 50-60 cells/frame were sampled every $3 \mathrm{sec}$. FURA-2 signals were recorded as an F340/F380 ratio, where F340 and F380 correspond to the background-subtracted fluorescence intensities at 340 and $380 \mathrm{~nm}$, respectively. The cytosolic $\left[\mathrm{Ca}^{2+}\right]$ was estimated from the ratio measurements using an established calibration method [21].

ER luminal $\mathrm{Ca}^{2+}$ was determined using HeLa-CES2 cells that contain ER lumenal carboxylesterase and allow efficient dye loading of the ER, as previously described [22]. Cells were loaded with $4 \mu \mathrm{M}$ Fluo5N AM (solubilized in Pluronic F-127) in HBSS (Gibco) for $15 \mathrm{~min}$ at $37^{\circ} \mathrm{C}$, washed with HBSS and incubated for another $30 \mathrm{~min}$ at $25^{\circ} \mathrm{C}$ to remove remaining cytosolic dye. After 1 min incubation in $\mathrm{Ca}^{2+}$-free buffer, buffer (0.1\% DMSO, solvent control), ophiobolin A $(100 \mu \mathrm{M})$ or TFP $(10 \mu \mathrm{M})$ were added, samples were measured for $2 \mathrm{~min}$, and then $1 \mu \mathrm{M}$ thapsigargin was added to unmask the passive $\mathrm{Ca}^{2+}$ efflux from the ER. After $8 \mathrm{~min}, 5 \mu \mathrm{M}$ ionomycin was applied to release the total $\mathrm{ER} \mathrm{Ca}^{2+}$ of the cells. Data were collected by the iMIC microscope with excitation at $490 \mathrm{~nm}$ and measurement of the emitted fluorescence at $530 \mathrm{~nm}$. Images containing 10-25 cells/frame were sampled every $3 \mathrm{~s}$. A $\tau_{1 / 2}$-value was calculated for each curve as the time point at which $50 \%$ reduction of fluorescence signal was achieved after addition of thapsigargin.

Data were analyzed using Excel 2007 and Origin 6.1.

\section{Results}

\section{Sec62 levels in cancer tissue predicts survival of} NSCLC patients

In our previous study, we detected SEC62 amplification and overexpression in NSCLC that did not correlate with patient age or sex but, at least for SCC, correlated with the appearance of lymph node metastases (higher Sec62 levels in $\mathrm{N}+$ tumors compared with $\mathrm{N} 0$ tumors) and the grade of differentiation (higher Sec62 levels in poorly differentiated G3 tumors compared with G2 tumors) [5]. Therefore, in the present study, we tested whether lower Sec62 levels in cancer tissue are associated with longer patient survival, which would indicate whether Sec62 can serve as a prognostic marker. We investigated the association between the rSec62 values of 70 NSCLC patients from our previous study [5] and these patients' survival starting from the date of diagnosis. Patients were divided into two groups based on their rSec62 value using a threshold of 2.1 (all patients, Figure 1A), 3 (SCC patients, Figure 1B) and 1.85 (AC patients, Figure $1 \mathrm{C}$ ), representing the median

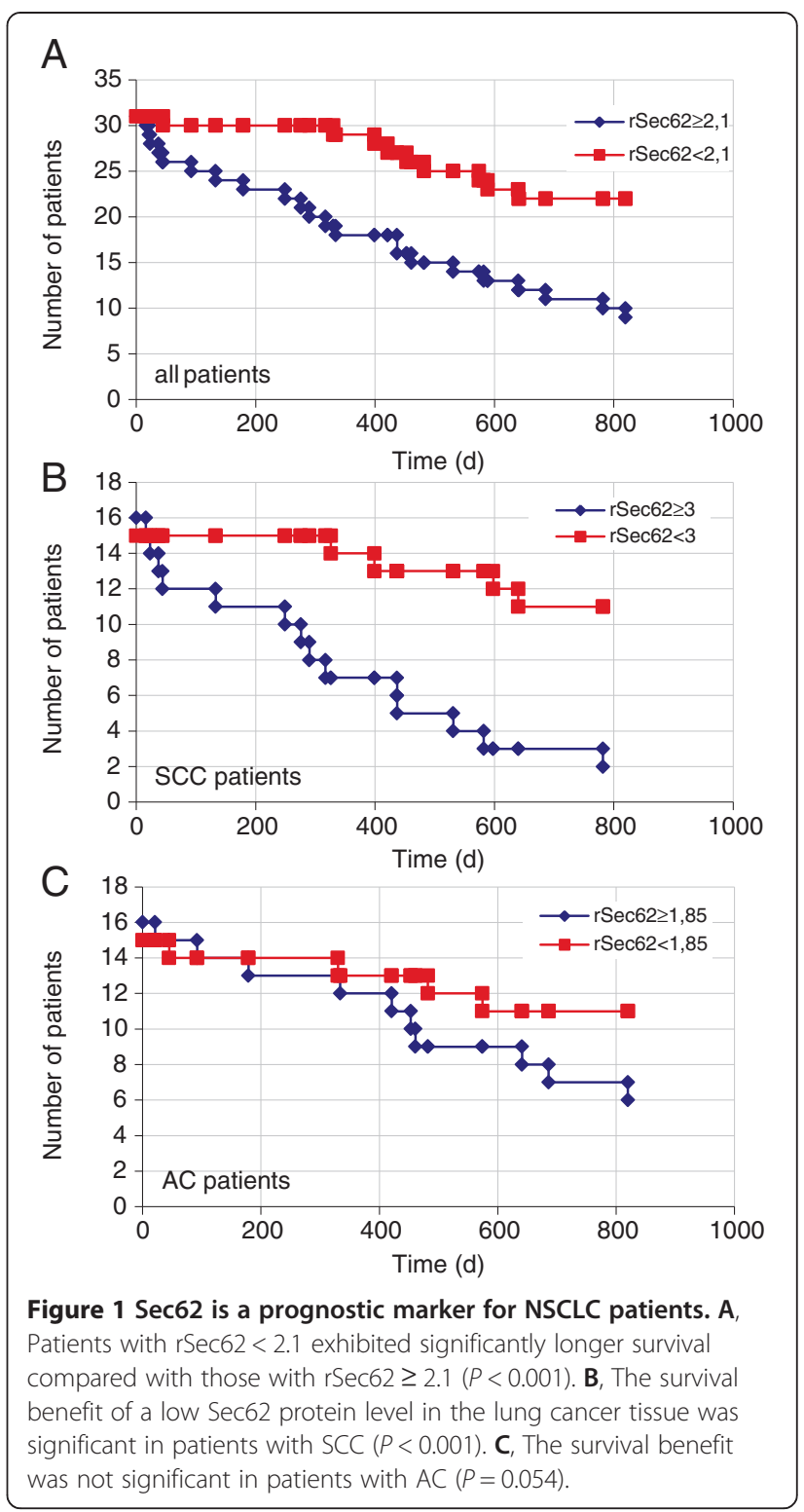

rSec62 value of the respective group. Survival analysis was visualized using Kaplan-Meier diagrams. Using the log-rank test, we observed a highly significant survival rate in the low rSec62 group compared with the high rSec62 group among all lung cancer patients, and SCC patients $(P=0.001$ for all NSCLC patients, $P=0.001$ for SCC patients, $P=0.054$ for $\mathrm{AC}$ patients). The clinical relevance of the Sec62 protein level for SCC of the lung is even more important given that the increased Sec62 protein level also protects tumor cells from thapsigargin therapy [13].

Treatment with calmodulin antagonists mimics changes in the cytosolic calcium concentration induced by SEC62 silencing

Previously, we have suggested SEC62 silencing as a possibility for overcoming the protective effect of SEC62 
overexpression against thapsigargin, as SEC62 silencing led to an increase in cytosolic $\mathrm{Ca}^{2+}$ and enhanced $\mathrm{Ca}^{2+}$ leakage from the ER in response to thapsigargin [13]. We also discovered a crucial influence of calmodulin on ER $\mathrm{Ca}^{2+}$ homeostasis; ER $\mathrm{Ca}^{2+}$ leakage is limited by $\mathrm{Ca}^{2+}$-dependent binding of calmodulin to the Sec61 complex $[17,23]$. The delivery of siRNAs for therapeutic applications is still problematic. Therefore, to determine whether Sec62 regulates calmodulin binding to the Sec61 complex or modulates the Sec61 complex, we examined the effects of the calmodulin antagonists, trifluoperazine (TFP) and ophiobolin $\mathrm{A}$, on $\mathrm{Ca}^{2+}$ homeostasis compared with the effects of siRNA-mediated Sec62 depletion. Interestingly, all three approaches resulted in a comparable increase in cytosolic $\mathrm{Ca}^{2+}$ with or without thapsigargin treatment (Figure 2A). The results strongly suggest that a similar molecular mechanism leads to dysregulation of cellular $\mathrm{Ca}^{2+}$ homeostasis after SEC62 silencing and after treatment with calmodulin antagonists.

To verify that indeed $\mathrm{Ca}^{2+}$ leakage from the ER is responsible for the increase in cytosolic $\mathrm{Ca}^{2+}$ concentration after treatment with ophiobolin A or TFP, we first used HeLa-CES2 cells in combination with Fluo5N to directly measure changes in ER luminal $\mathrm{Ca}^{2+}$. We observed an initial $\mathrm{Ca}^{2+}$-release from the ER after addition of calmodulin antagonists and a significantly higher efflux in the ophiobolin A or TFP pretreated cells in response to thapsigargin (Figure $2 \mathrm{~B}$ ), with $\mathrm{T}_{1 / 2}$-values of $163 \mathrm{~s}$ for the buffer control, $87 \mathrm{~s}$ after pretreatment with ophiobolin A and $65 \mathrm{~s}$ after pretreatment with TFP. Next, we asked if the calmodulin antagonists influence the store operated calcium entry (SOCE). To this end, we measured the cytosolic $\mathrm{Ca}^{2+}$ concentration after treating the cells externally with a $\mathrm{Ca}^{2+}$-containing buffer instead of thapsigargin and EGTA. These experiments disclosed that SOCE was also significantly stimulated by pretreatment with calmodulin antagonists. Moreover, a comparison between cells treated with control siRNA and cells treated with two different siRNAs directed against SEC61A1 indicated a crucial function of the Sec61 channel in SOCE under these conditions (Figure 2C). We note that we used a HeLa cell-based model system rather than lung cancer cells for two main reasons. First, the HeLa cells provide a well-established model system for SEC61A1 or SEC62 gene silencing, and live-cell $\mathrm{Ca}^{2+}$ imaging. Second, we were able to compare the results of live-cell $\mathrm{Ca}^{2+}$ imaging experiments on cells treated with SEC61A1 or SEC62 siRNA with our previous observations (Figure 2A-D) [13,24].

Furthermore, we examined whether the effect of Sec62 on $\mathrm{ER} \mathrm{Ca}^{2+}$ leakage can be linked to the $\mathrm{Ca}^{2+}$-permeable Sec61 complex as has been previously shown for the effects of TFP and ophiobolin A [17,24]. To address this question, we treated HeLa cells for $96 \mathrm{~h}$ with SEC62 siRNA, SEC61A1 siRNA, SEC62 plus SEC61A1 siRNA, or a negative control siRNA. Simultaneous silencing of SEC61A1 and SEC62 by siRNA had an inhibitory effect on SEC62 silencing-induced $\mathrm{Ca}^{2+}$ efflux (Figure 2D). Western blot analysis indicated that the silencing efficiency of both siRNAs was $>80 \%$ (Figure 2D, insert). Thus, calmodulin antagonists and Sec62 contribute to reducing $\mathrm{Ca}^{2+}$ leakage from the ER at the Sec61 complex level. As has already been shown for calmodulin [17], Sec62 presumably acts by direct interaction with Sec61 $\alpha$.

Peptide binding experiments were carried out to directly demonstrate the putative interaction of Sec62 with Sec61 $\alpha$ and identify the Sec62 binding site. Peptide spots that correspond to the human Sec61 $\alpha$ were synthesized on cellulose membranes. The peptides consisted of 12 amino acid residues and overlapped adjacent peptides by 10 residues. The peptides were incubated with the $\mathrm{C}$-terminal cytosolic domain of the double-spanning membrane protein, Sec62. The C-terminal domain of Sec62 (Sec62C) preferentially bound to the N-terminal peptide of Sec61 $\alpha$ (amino acid residues 1-16; Figure 2E, insert). In subsequent SPR spectroscopy analysis (Figure 2E), the interaction of Sec62C with the N-terminal peptide of Sec61 $\alpha$ was confirmed. Sec62C showed more pronounced binding to Sec61 $\alpha$ in the absence of $\mathrm{Ca}^{2+}$ than in its presence. In silico analysis of the Sec62 sequence (www.bioinformatics. org/calpred/ index.html) identified a potential EF hand in the C-terminal domain of vertebrate Sec62 (Figure 3A), which may explain this $\mathrm{Ca}^{2+}$ effect (amino acid residues 308-319, see below).

\section{Mutation in a predicted calcium-binding motif in the C-terminal domain of Sec62 leads to a dominant-negative effect on cell migration and ER calcium leakage}

Previously, we showed that Sec62 depletion inhibits the spread of metastatic tumor cells and increases cell sensitivity to $\mathrm{Ca}^{2+}$-driven ER stress [12,13]. By introducing the $\mathrm{D} 308 \mathrm{~A}$ mutation into the predicted $\mathrm{Ca}^{2+}$-binding motif within the C-terminal domain of Sec62, we confirmed the function of Sec62 in regulating ER $\mathrm{Ca}^{2+}$ homeostasis (Figure 3A). In this experiment, the expression of plasmidencoded SEC62-WT or SEC62 $2_{\mathrm{D} 308 \mathrm{~A}}$ was evaluated by quantitative western blot analysis of the stably transfected HEK293 cell lines. We observed a nine-fold increase in Sec62 in the presence of pSEC62-WT and an almost five-fold increase in Sec62 in the presence of pSEC62 $2308 \mathrm{~A}$ in comparison with the control plasmid (Figure $3 \mathrm{~B}$ ). We then compared stably transfected HEK293 cells overexpressing the plasmid-encoded mutant SEC62 (pSEC62 ${ }_{D 308 A}$-IRES-GFP) with cells overexpressing SEC62WT (pSEC62-IRES-GFP). Overproduction of Sec62-WT led to increased migration, which is in agreement with our previous observations [5]. In contrast, overproduction of the mutant Sec62 protein, even in the presence of the endogenous Sec62-WT protein, reduced cell migration 


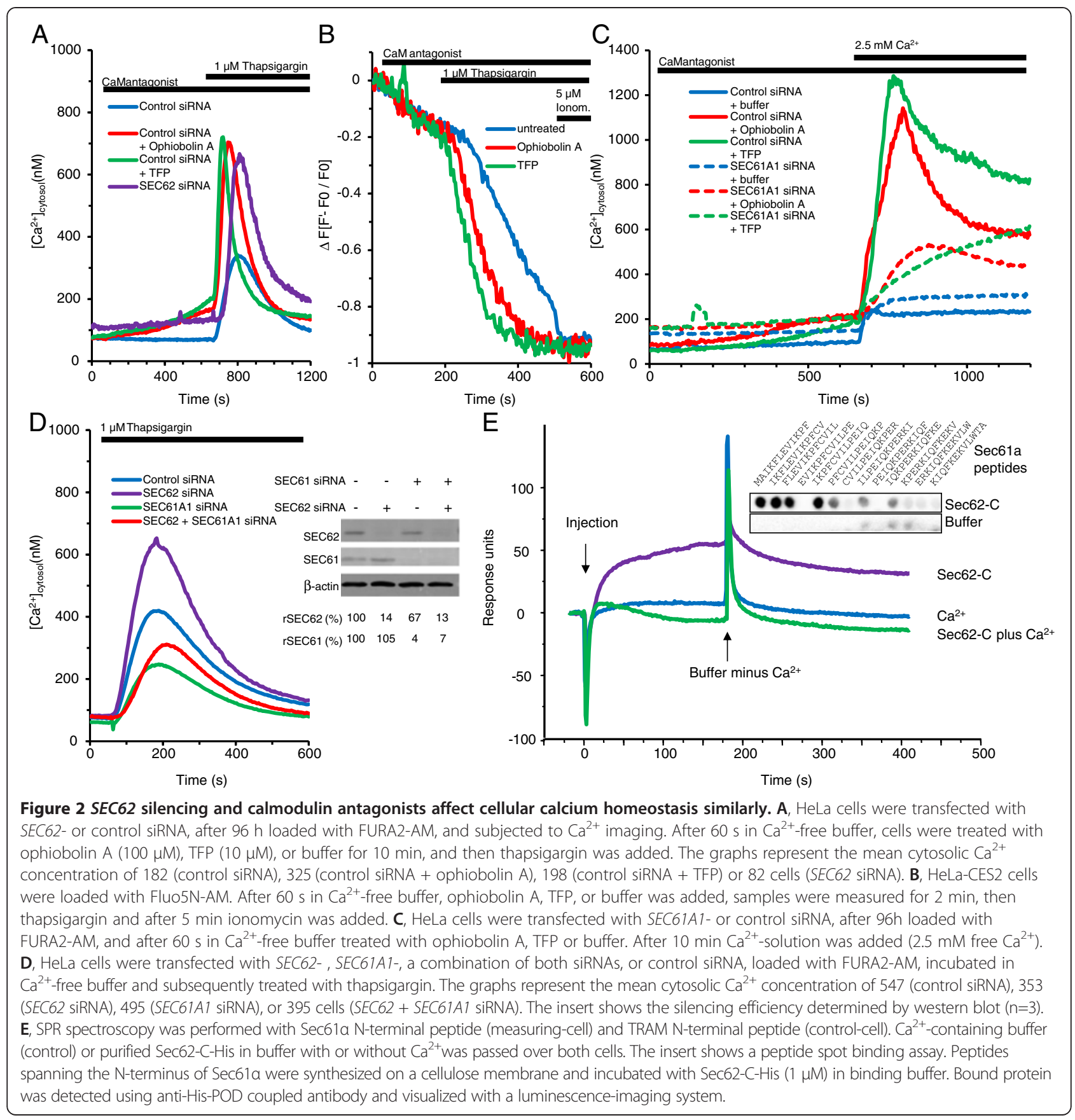

in a manner similar to SEC62 silencing (Figure 3C). Also, the sensitivity to thapsigargin (Figure 3D) and thapsigargin-induced $\mathrm{Ca}^{2+}$ leakage from the ER increased after $S E C 62_{\mathrm{D} 308 \mathrm{~A}}$ expression (Figure 3E). Overall, SEC62WT overexpression did not affect cell growth or ER $\mathrm{Ca}^{2+}$ leakage, whereas $S E C 62_{\mathrm{D} 308 \mathrm{~A}}$ overexpression led to a phenotype comparable to that of SEC62 silencing. These experiments clearly indicate a direct influence of the predicted EF hand motif in Sec62 on ER $\mathrm{Ca}^{2+}$ homeostasis and its direct connection to the observed phenotypes.
HeLa and HEK293 cells are more sensitive to TFP treatment than PC3 cells

To study the influence of TFP and ophiobolin A on cellular processes other than $\mathrm{Ca}^{2+}$ homeostasis, we analyzed the proliferation of PC3 and HeLa cells in the presence of these two calmodulin antagonists. We also analyzed HEK293 cells with respect to their TFP sensitivity. The main aim of this set of experiments was to determine the TFP and ophiobolin A concentrations that do not inhibit cell growth in subsequent cell migration or thapsigargin 


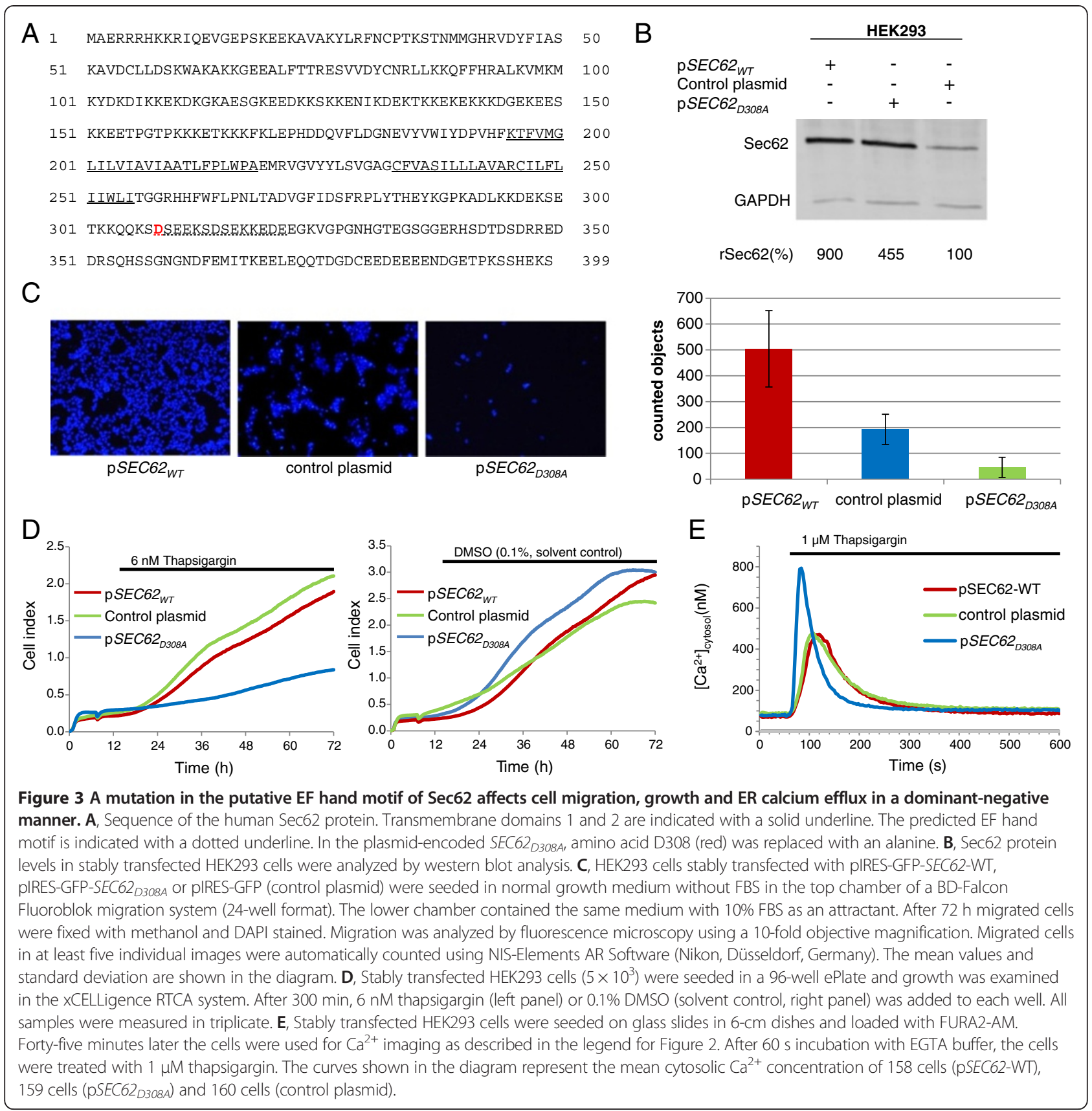

sensitivity studies. PC3 and HeLa cells exhibited the same sensitivity to ophiobolin A; both cell lines exhibited normal growth behavior up to a concentration of $500 \mathrm{nM}$, whereas higher concentrations significantly inhibited cell growth (Figure 4A). In contrast, PC3 cells tolerated TFP up to $24 \mu \mathrm{M}$, while HeLa cells exhibited a time-limited growth inhibition between 24 and $60 \mathrm{~h}$ after adding the compound, indicating that HeLa cells were more sensitive to TFP treatment than PC3 cells (Figure 4B). HEK293 cells exhibited normal proliferation with up to $8 \mu \mathrm{M}$ of TFP in the medium, whereas cell growth was almost completely inhibited with higher concentrations. Based on these findings, we used concentrations of up to $250 \mathrm{nM}$ of ophiobolin A and up to $8 \mu \mathrm{M}$ of TFP as non-growthinhibiting conditions for all cell lines in the subsequent experiments. Interestingly, the HeLa and HEK293 cells, which were more sensitive to TFP treatment, also expressed lower levels of Sec62 protein compared with PC3 cells. This difference was not because of a lower ER content, as the analyzed cell lines expressed similar levels of the ER chaperone, BiP (Figure 4C). The sensitivity of different cell lines to calmodulin antagonists may correlate with their specific Sec62 protein content, as indicated by our previous finding that Sec62 levels are crucial for cell tolerance 


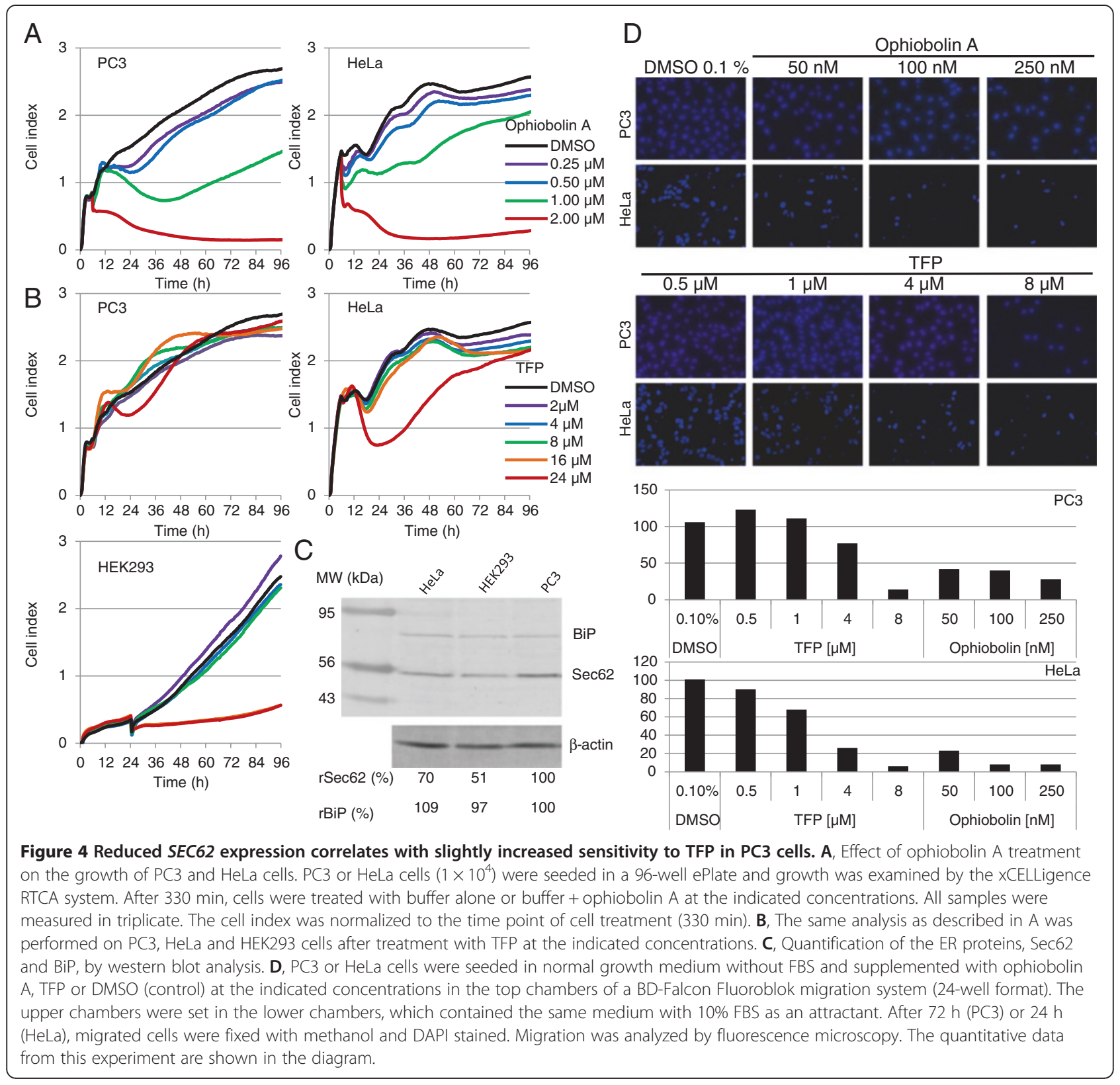

against thapsigargin-induced ER stress [13]. The present findings affirmed the direct role of Sec62 in the cellular response to $\mathrm{Ca}^{2+}$-driven ER stress.

Treatment with calmodulin antagonists and SEC62 silencing result in comparable cellular phenotypes

Next, we investigated whether a strongly reduced migration potential and increased sensitivity to thapsigargin-induced ER stress can also be caused by TFP or ophiobolin A treatment. First, the cell migration of PC3 and HeLa cells was examined in the presence of increasing amounts of ophiobolin A or TFP. We found a dose-dependent reduction in cell migration with both cell lines with both treatments (Figure 4D). Again, HeLa cells were more sensitive to the treatments than PC3 cells. To confirm the results, we tested different human lung (H1299, A549 and BC01) and thyroid cancer cell lines (BHT101 and ML1). We have previously reported reduced migration of these cell lines after transfection with SEC62 siRNA [5]. Here, we found that $4 \mu \mathrm{M}$ TFP and $100 \mathrm{nM}$ ophiobolin A had the same effect on each cell line, strongly inhibiting cell migration without affecting cell proliferation (Figure 5A).

Because Sec62 depletion by siRNA transfection alone was sufficient to block cell migration in previous experiments [12], we tested whether SEC62 overexpression can rescue ophiobolin A- or TFP-treated cells. We used HEK293 cells, which only poorly migrate without treatment but can be stimulated to migrate by the addition of 


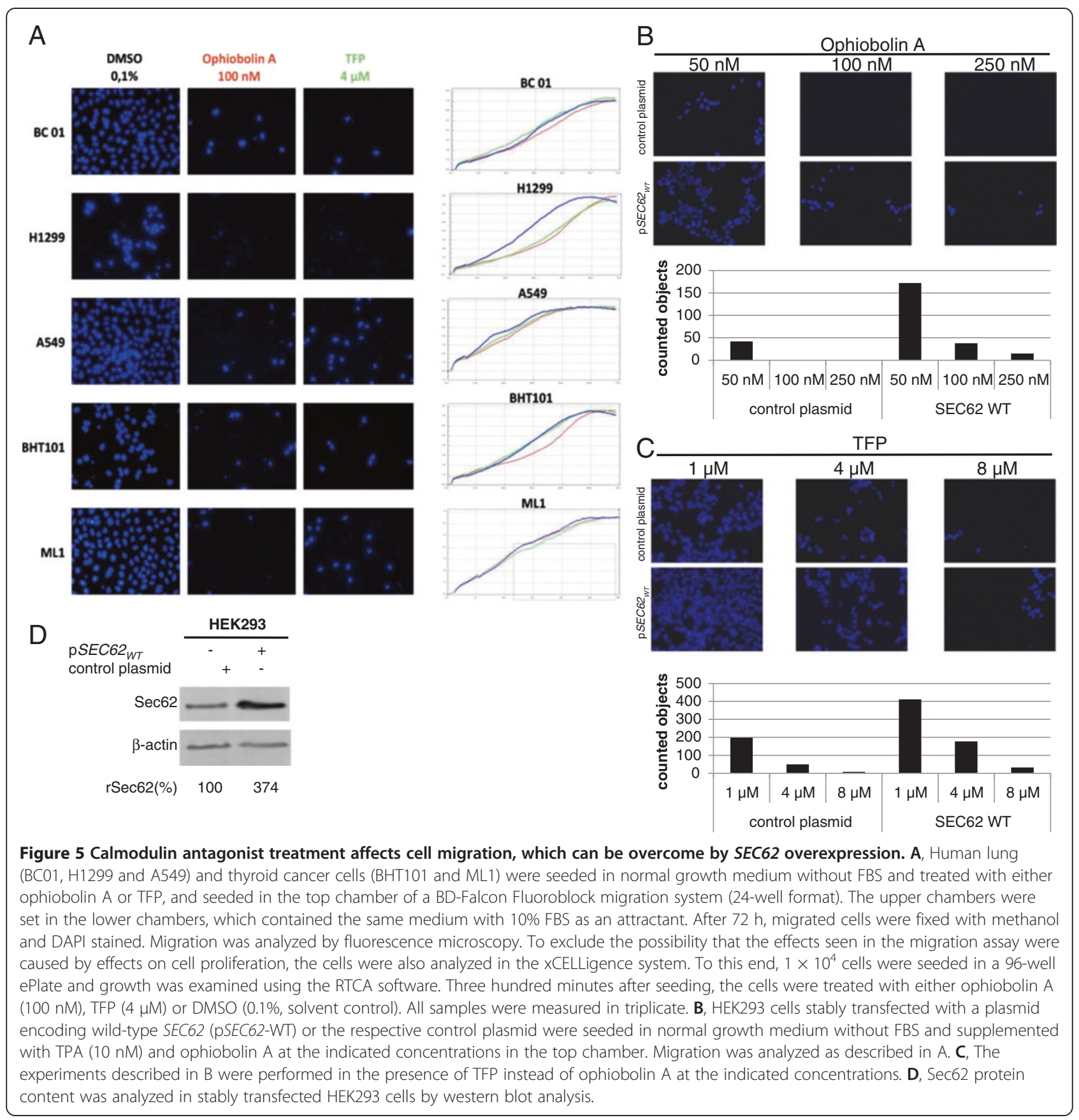

12-O-tetradecanoylphorbol 13-acetate (TPA), a drug that down-regulates agonist-driven $\mathrm{Ca}^{2+}$ release from the ER [25] and stimulates cell migration [26,27]. We compared HEK293 cells stably transfected with a pIRES-GFP vector (control plasmid) and HEK293 cells stably overexpressing plasmid-encoded SEC62 (pSEC62-IRES-GPF). The migration of the control plasmid-transfected HEK293 cells was completely inhibited by $100 \mathrm{nM}$ ophiobolin A or $8 \mu \mathrm{M}$ TFP (Figure 5B and C). However, cells overexpressing SEC62 still migrated under these conditions (Figure $5 \mathrm{~B}$ and $\mathrm{C}$ ), indicating that the Sec62 protein content resulted in higher cell resistance to treatment with calmodulin antagonists. Quantitative western blot analysis confirmed a four-fold increase in Sec62 in the pSEC62-WT-carrying HEK293 cells (Figure 5D). These observations support a $\mathrm{Ca}^{2+}$-dependent influence of Sec62 on cell migration.

\section{Growth inhibition induced by calmodulin antagonists is} enhanced by Sec62 depletion

Because treatment with calmodulin antagonists led to the same phenotype as Sec62 depletion with respect to cell migration, we next investigated whether this was also true 
for the increased thapsigargin sensitivity of the cells. PC3 cells were transfected with control siRNA or siRNA specifically directed against the SEC62 mRNA, followed by treatment with $10 \mathrm{nM}$ thapsigargin in the presence of $8 \mu \mathrm{M}$ TFP or $0.1 \%$ DMSO (solvent control). Sec62-depleted cells exhibited greater sensitivity to thapsigargin and similar behavior to control siRNA-transfected cells after TFP treatment, indicating a slightly weaker decline in the growth rate (Figure $6 \mathrm{~A}$ and $\mathrm{B}$ ). Combined treatment with SEC62 siRNA and $8 \mu \mathrm{M}$ TFP resulted in even stronger growth inhibition, indicating an additive effect of SEC62 silencing and calmodulin antagonist treatment (Figure 6A and $\mathrm{B}$ ). This possible additive effect also appeared with respect to cell migration (Figure 6C and D). Taken together, these results indicate that growth inhibition by treatment with calmodulin antagonists and reduction in cellular Sec62 protein affect the same mechanisms, providing valuable hints
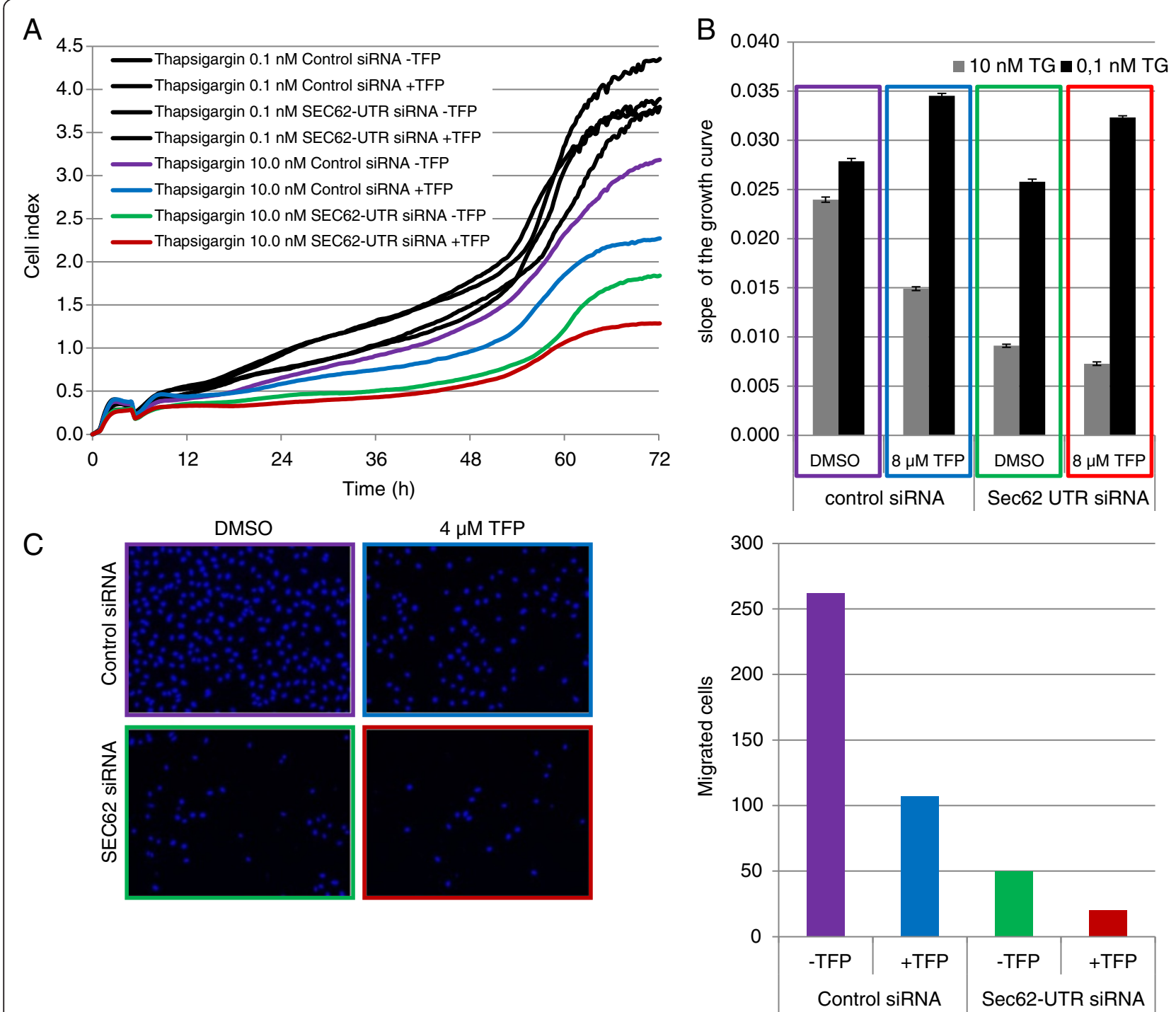

Figure 6 SEC62 silencing and TFP treatment additively affect cell growth and migration in PC3 cells. A, Cells were seeded in 6-cm dishes and transfected with SEC62 siRNA or control siRNA $24 \mathrm{~h}$ and $48 \mathrm{~h}$ after seeding. Twenty-four hours after the second transfection, $5 \times 10^{3} \mathrm{PC} 3 \mathrm{cells}$ were seeded in a 96-well ePlate and growth was examined using the XCELLigence RTCA system. After 300 min, the cells were treated with $10 \mathrm{nM}$ thapsigargin or $0.1 \mathrm{nM}$ thapsigargin in the presence of DMSO $(0.1 \%$, solvent control) or TFP $(8 \mu \mathrm{M})$. All samples were measured in triplicate. B, The slopes of the growth curves shown in A between 8-72 $\mathrm{h}$ were calculated using the RTCA software. The error bars indicate standard deviations. C, Cells were treated with SEC62 siRNA or control siRNA as described in A. Twenty-four hours after the second transfection, cells were seeded in normal growth medium without FBS and supplemented with either $4 \mu \mathrm{M}$ TFP or $0.1 \%$ DMSO (control) in the top chamber of a BD-Falcon Fluoroblok migration system (24-well format). The lower chamber contained the same medium with 10\% FBS as an attractant. After $72 \mathrm{~h}$, migrated PC3 cells were fixed with methanol and DAPI stained. Migration was analyzed by fluorescence microscopy. D, Migrated cells from C were automatically counted using the NIS-Elements AR Software (Nikon). 
regarding the function of Sec62 under cellular stress conditions.

\section{Discussion}

\section{Sec62 as a new prognostic marker for NSCLC patients}

Because SEC62 silencing inhibits cancer cell migration and increases sensitivity to $\mathrm{Ca}^{2+}$-driven cellular stress, we investigated whether Sec62 represents not only a possible new target for anti-cancer therapies, but also a prognostic marker for lung cancer patients. A low rSec62 value predicts increased survival of NSCLC patients, with an even stronger predictive potential for SCC patients. Together with our previous findings that SEC62 is overexpressed and correlates with lymph node metastasis ( $\mathrm{N}+\mathrm{vs}$. N0) and cancer progression (G3 vs. G2) in SCC of the lung [5], the results indicate that Sec62 plays a crucial role in lung cancer biology and is both a promising new target for cancer therapy and a reliable marker of clinical outcomes. Additional studies are needed to determine whether the role of Sec62 as a prognostic marker is solely because of the tumor cells' dependency on a sufficient Sec62 level to enable metastasis and resistance to $\mathrm{Ca}^{2+}$-driven cellular stress, or whether Sec62 has additional contributing functions.

\section{Phenotypic analogy of cellular calcium changes following treatment with calmodulin antagonists provides new insight into molecular events in Sec62-depleted cells}

We have previously reported strong inhibition of cell migration in different human cancer cells after Sec62 depletion by transfection with SEC62 siRNA [5,12]. SEC62 silencing markedly increased cell sensitivity to ER stress induced by dysregulation of cellular $\mathrm{Ca}^{2+}$ homeostasis, as shown by the more pronounced growth inhibition of Sec62-depleted cells after treatment with the SERCA inhibitor, thapsigargin, compared with control cells $[5,13]$. These results indicate that Sec62 plays a crucial role in cell migration and the ER stress response, particularly in cancer cells. However, we could not determine the molecular mechanisms responsible for these phenomena, as the function of Sec62 is only partially understood, even under physiological conditions, with some evidence for a role in protein transport at the ER of mammalian cells $[9,10]$. Sec62 could be involved in the transport of a particular subset of precursor proteins, including proteins that play crucial roles in cell migration and the ER stress response. However, we propose a model in which Sec62 influences these processes by regulating cellular $\mathrm{Ca}^{2+}$ homeostasis (Figure 7). This possibility is supported by the key role of $\mathrm{Ca}^{2+}$ in cell migration and ER stress [14,28-30], the potential EF hand motif in the cytosolic C-terminus of Sec62, the increase in basal cellular $\mathrm{Ca}^{2+}$ in response to SEC62 silencing, and the markedly elevated cytosolic $\mathrm{Ca}^{2+}$ in response to thapsigargin treatment after SEC62 silencing [13]. Though sparse evidence supports the first theory, Sec62's influence on $\mathrm{Ca}^{2+}$ homeostasis is strongly supported by the present findings. Here, we showed that Sec62 depletion by siRNA transfection and treatment with calmodulin antagonists resulted in very similar changes in basal cellular $\mathrm{Ca}^{2+}$ levels and increased cytosolic $\mathrm{Ca}^{2+}$ concentrations after thapsigargin treatment. We also found that the treatment of different human cancer cells with calmodulin antagonists led to the same cellular phenotypes as observed after SEC62 silencing, namely cell migration inhibition and markedly higher cell sensitivity to thapsigargininduced ER stress. The crucial role of Sec62 in cellular $\mathrm{Ca}^{2+}$ homeostasis was further supported by the synergistic action of treatment with SEC62 siRNA and calmodulin antagonists in regard to the sensitivity to thapsigargininduced ER stress and by the rescue of cell migration by SEC62 overexpression in cells pretreated with calmodulin antagonists.

Furthermore, the dominant-negative phenotype induced by mutation of the predicted EF hand motif in the Sec62 protein, which was completely congruent with the effects of Sec62 depletion or treatment with calmodulin antagonists, strongly points to a direct regulation of Sec62 function by $\mathrm{Ca}^{2+}$ binding to the motif. The Sec61 complex has recently been shown to form an important $\mathrm{Ca}^{2+}$ leakage channel in the ER, the major cellular $\mathrm{Ca}^{2+}$ reservoir, and that $\mathrm{Ca}^{2+}$ efflux via this polypeptide pore is regulated by calmodulin [23] and the ER luminal Hsp70 chaperone, $\mathrm{BiP}$ [31]. Taken together with our new findings that $\mathrm{Ca}^{2+}$ efflux from the ER after Sec62 depletion occurs through the Sec61 complex, we propose a model in which Sec62 is an additional regulator of the Sec61 $\mathrm{Ca}^{2+}$ leakage channel. Sec62 regulates $\mathrm{Ca}^{2+}$ leakage via a direct interaction with Sec61. The association of these two proteins has already been demonstrated $[7,8]$ and has been found to be $\mathrm{Ca}^{2+}$ sensitive (Figure 2D). Following our model, Sec62 senses emanating $\mathrm{Ca}^{2+}$ via a microdomain in close proximity to the Sec61 channel. After $\mathrm{Ca}^{2+}$ binding, Sec62 binding to Sec61 is relieved, thereby uncovering the binding site and facilitating the binding of $\mathrm{Ca}^{2+}$-calmodulin to Sec61 on the cytosolic surface of the ER, leading to closure of the channel (Figure 7A and E). In this model, the Sec62 variant with the mutated $\mathrm{EF}$ hand $\left(\mathrm{Sec}_{62} 2_{\mathrm{D} 308 \mathrm{~A}}\right)$ is no longer able to sense the emanating $\mathrm{Ca}^{2+}$, and thus closure of the Sec61 channel by $\mathrm{Ca}^{2+}$-calmodulin binding would not occur, which explains the increased $\mathrm{Ca}^{2+}$ response observed in our live-cell $\mathrm{Ca}^{2+}$ imaging experiments. An additional mode of action of Sec62 on the luminal side is possible via a role in the recruitment of $\mathrm{BiP}$ as a $\mathrm{Ca}^{2+}$ efflux-limiting factor via its interaction with the J-domain-containing Hsp40 protein, Sec63 $[7,8,11,32]$. 


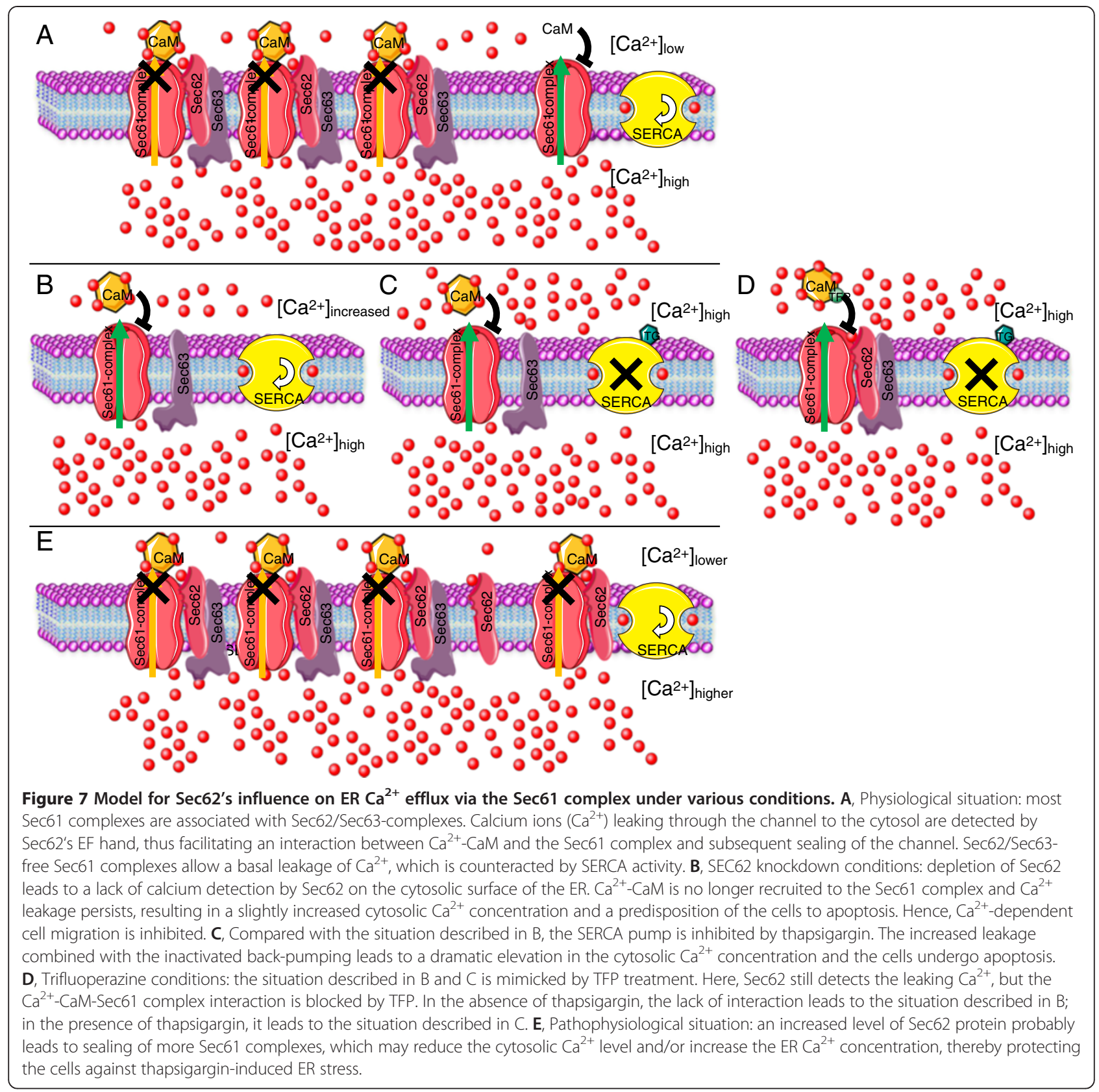

Mimicking the Sec62-depletion phenotype with small molecule treatment as a possible new therapeutic option for cancer patients

Previous studies have shown that Sec62 depletion by transfection with SEC62 siRNA leads to cell migration inhibition and higher sensitivity to ER stress induced by $\mathrm{Ca}^{2+}$ dysregulation $[5,12,13]$. Therefore, SEC62 silencing seems to provide a potential approach for cancer treatment, especially lung and thyroid cancer, as such treatment could lead to reduced metastatic spread of tumor cells and higher sensitivity to chemotherapies working via the induction of ER stress. However, despite intensive studies over the past few decades [33-36], RNA interference remains unfeasible for clinical treatment of human diseases, mainly because of toxic side effects and problems in achieving adequate concentrations in the target tissues [37]. Our present results provide a potential strategy for overcoming these problems with tumors that overproduce Sec62.

In the current study, we showed that treatment of different human cancer cells with calmodulin antagonists induced a Sec62-depletion phenotype, including cell migration inhibition and higher sensitivity to $\mathrm{Ca}^{2+}$-driven ER stress. The same effects on tumor cell biology can be expected by treating patients with these substances, 
which have already been intensively discussed as potential anti-metastatic and anti-proliferative drugs [38-43]. In particular, TFP appears to be a promising candidate for trials in animal models, and in human patients, because it has previously been used as an antipsychotic and antiemetic drug $[44,45]$. Treatment with calmodulin antagonists could also provide the means for overcoming problems with treating patients with high levels of Sec62 protein in tumor cells [13]; here, a personalized therapeutic approach that also targets the SERCA pump using thapsigargin or tissue-specific peptide conjugates of thapsigargin appears to be promising [46-50]. Based on the present results, we propose combined treatment with TFP and targeted thapsigargin as a powerful new strategy for treating patients with SCC of the lung (Figure 7D), which is especially important because the therapeutic options for this malignancy are very limited and increased levels of Sec62 are a significant disadvantage in regard to survival.

\section{Conclusions}

The present study describes a new function of Sec62 in regulating the calmodulin-mediated sealing of the Sec61 $\mathrm{Ca}^{2+}$ leakage channel in the ER, which may explain how the up-regulation of SEC62 expression results in reduced survival among lung cancer patients. Furthermore, it provides the first molecular insight into the mechanism of resistance of Sec62-overproducing tumor cells to treatment with thapsigargin. Using calmodulin antagonists, including TFP, we can inhibit cancer cell migration and overcome the problem of Sec62 overproduction in response to thapsigargin, which may also improve the treatment of these cancer entities in future combinatorial therapeutic strategies.

\section{Competing interests}

The authors' declare no potential conflicts of interest with respect to the research, authorship, and/or publication of this article.

\section{Authors' contributions}

$\mathrm{ML}$ performed $\mathrm{Ca}^{2+}$ imaging, cell migration and real-time cell analysis experiments using the Sec62 $2308 \mathrm{~A}$ variant (Figure 3 ), the human thyroid and lung cancer cell lines (Figure 5A), compared Sec62 levels in different cell lines by western blot analysis (Figure 4C), and participated in writing the manuscript. SS generated the point mutation in SEC62 and performed $\mathrm{Ca}^{2+}$ imaging experiments with combined knockdown of SEC61A1 and SEC62 (Figure 2D). NS performed $\mathrm{Ca}^{2+}$ imaging experiments with calmodulin antagonists (Figure 2A), measurements of ER lumenal $\mathrm{Ca}^{2+}$ (Figure 2B) and of SOCE (Figure 2C). MJ performed protein-peptide interaction studies (Figure 2D). JL, FL and HJS analyzed the clinical data and performed statistical analysis (Figure 1). AC supervised all $\mathrm{Ca}^{2+}$ imaging experiments. RZ supervised all cell biological experiments and participated in writing the manuscript. MG performed real-time cell analysis (Figure 4 and 6), cell migration analysis (Figure 5 and 6), generated the stable HEK293 pSEC62-IRES-GFP and pIRES-GFP cell lines and participated in writing the manuscript. All authors read and approved the final manuscript.

\section{Acknowledgments}

This work was supported by a grant from the Deutsche Forschungsgemeinschaft (FOR967, R. Zimmermann) and a donation by Freunde des Universitätsklinikums des Saarlandes (J. Linxweiler and M. Linxweiler).

\section{Author details}

'Department of Medical Biochemistry and Molecular Biology, Saarland University, Homburg, Saarland, Germany. ${ }^{2}$ Department of Thoracic and Cardiovascular Surgery, Saarland University Hospital, Homburg, Saarland, Germany. ${ }^{3}$ Experimental and Clinical Pharmacology and Toxicology, Saarland University, 66421 Homburg, Saarland, Germany.

Received: 10 April 2013 Accepted: 27 November 2013

Published: 5 December 2013

\section{References}

1. Ferlay J, Shin HR, Bray F, Forman D, Mathers C, Parkin DM: Estimates of worldwide burden of cancer in 2008: GLOBOCAN 2008. Int J Cancer 2010, 127:2893-2917.

2. Beaglehole R, Bonita R: Global public health: a scorecard. Lancet 2008, 372:1988-1996.

3. Bray Fl, Weiderpass E: Lung cancer mortality trends in 36 European countries: secular trends and birth cohort patterns by sex and region 1970-2007. Int J Cancer 2009, 126:1454-1466.

4. Herbst RS, Heymach JV, Lippman SM: Lung cancer. N Engl J Med 2008 359:1367-1380.

5. Linxweiler $M$, Linxweiler J, Barth $M$, Benedix J, Jung V, Kim YJ, Bohle RM Zimmermann R, Greiner M: Sec62 bridges the gap from 3q amplification to molecular cell biology in non-small cell lung cancer. Am J Pathol 2012, 180:473-483.

6. Panzner S, Dreier L, Hartmann E, Kostka S, Rapoport TA: Posttranslational protein transport in yeast reconstituted with a purified complex of Sec proteins and Kar2p. Cell 1995, 81:561-570.

7. Meyer HA, Grau H, Kraft R, Kostka S, Prehn S, Kalies KU, Hartmann E: Mammalian Sec61 is associated with Sec62 and Sec63. J Biol Chem 2000, 275:14550-14557.

8. Tyedmers J, Lerner M, Bies C, Dudek J, Skowronek MH, Haas IG, Heim N, Nastainczyk W, Volkmer J, Zimmermann R: Homologs of the yeast Sec complex subunits Sec62p and Sec63p are abundant proteins in dog pancreas microsomes. Proc Natl Acad Sci USA 2000, 97:7214-7219.

9. Lakkaraju AK, Thankappan R, Mary C, Garrison JL, Taunton J, Strub K: Efficient secretion of small proteins in mammalian cells relies on Sec62-dependent posttranslational translocation. Mol Biol Cell 2012, 23:2712-2722.

10. Lang S, Benedix J, Fedeles SV, Schorr S, Schirra C, Schauble N, Jalal C Greiner M, Hassdenteufel S, Tatzelt J, et al: Different effects of Sec61alpha, Sec62 and Sec63 depletion on transport of polypeptides into the endoplasmic reticulum of mammalian cells. J Cell Sci 2012, 125:1958-1969.

11. Muller L, Diaz de Escauriaza M, Lajoie P, Theis M, Jung M, Muller A, Burgard C, Greiner M, Snapp EL, Dudek J, Zimmermann R: Evolutionary gain of function for the ER membrane protein Sec62 from yeast to humans. Mol Biol Cell 2010, 21:691-703.

12. Greiner M, Kreutzer B, Jung V, Grobholz R, Hasenfus A, Stöhr RF, Tornillo L, Dudek J, Stöckle M, Unteregger G, et al: Silencing of the SEC62 gene inhibits migratory and invasive potential of various tumor cells. Int J Cancer 2011, 128:2284-2295.

13. Greiner M, Kreutzer B, Lang S, Jung V, Adolpho C, Unteregger G, Zimmermann R, Wullich B: Sec62 protein content is crucial for the ER stress tolerance of prostate cancer. Prostate 2011, 71:1074-1083.

14. Calfon M, Zeng H, Urano F, Till JH, Hubbard SR, Harding HP, Clark SG, Ron D: IRE1 couples endoplasmic reticulum load to secretory capacity by processing the XBP-1 mRNA. Nature 2002, 415:92-96.

15. Nishitoh H, Matsuzawa A, Tobiume K, Saegusa K, Takeda K, Inoue K, Hori S, Kakizuka A, Ichijo H: ASK1 is essential for endoplasmic reticulum stress-induced neuronal cell death triggered by expanded polyglutamine repeats. Genes Dev 2002, 16:1345-1355.

16. Huang JB, Kindzelskii AL, Clark AJ, Petty HR: Identification of channels promoting calcium spikes and waves in HT1080 tumor cells: their apparent roles in cell motility and invasion. Cancer Res 2004, 64:2482-2489.

17. Erdmann F, Schauble N, Lang S, Jung M, Honigmann A, Ahmad M, Dudek J, Benedix J, Harsman A, Kopp A, et al: Interaction of calmodulin with Sec61alpha limits $\mathrm{Ca} 2+$ leakage from the endoplasmic reticulum. Embo J 2011, 30:17-31.

18. Hilpert K, Winkler DF, Hancock RE: Peptide arrays on cellulose support: SPOT synthesis, a time and cost efficient method for synthesis of large numbers of peptides in a parallel and addressable fashion. Nat Protoc 2007, 2:1333-1349. 
19. Aneiros E, Philipp S, Lis A, Freichel M, Cavalie A: Modulation of Ca2+ signaling by $\mathrm{Na}+/ \mathrm{Ca} 2+$ exchangers in mast cells. J Immuno/ 2005, 174:119-130.

20. Gross SA, Guzman GA, Wissenbach U, Philipp SE, Zhu MX, Bruns D, Cavalie A: TRPC5 is a $\mathrm{Ca} 2+-$ activated channel functionally coupled to Ca2 + -selective ion channels. J Biol Chem 2009, 284:34423-34432.

21. Lomax RB, Camello C, Van Coppenolle F, Petersen OH, Tepikin AV: Basal and physiological $\mathrm{Ca}(2+)$ leak from the endoplasmic reticulum of pancreatic acinar cells. Second messenger-activated channels and translocons J Biol Chem 2002, 277:26479-26485.

22. Rehberg M, Lepier A, Solchenberger B, Osten P, Blum R: A new non-disruptive strategy to target calcium indicator dyes to the endoplasmic reticulum. Cell Calcium 2008, 44:386-399.

23. Harsman A, Kopp A, Wagner R, Zimmermann R, Jung M: Calmodulin regulation of the calcium-leak channel Sec61 is unique to vertebrates. Channels (Austin) 2011, 5:293-298.

24. Lang S, Schauble N, Cavalie A, Zimmermann R: Live cell calcium imaging combined with siRNA mediated gene silencing identifies $\mathrm{Ca}(2)(+)$ leak channels in the ER membrane and their regulatory mechanisms. $J$ Vis Exp 2011.

25. Chen $L$, Meng $Q$, Jing $X, X u P$, Luo $D$ : A role for protein kinase $C$ in the regulation of membrane fluidity and $\mathrm{Ca} 2+$ flux at the endoplasmic reticulum and plasma membranes of HEK293 and Jurkat cells. Cell Signal 2011, 23:497-505.

26. Nabeshima K, Komada N, Kishi J, Koita H, Inoue T, Hayakawa T, Koono M: TPA-enhanced invasion of Matrigel associated with augmentation of cell motility but not metalloproteinase activity in a highly metastatic variant (L-10) of human rectal adenocarcinoma cell line RCM-1. Int J Cancer 1993, 55:974-981.

27. Lin CW, Shen SC, Chien CC, Yang LY, Shia LT, Chen YC: 12-Otetradecanoylphorbol-13-acetate-induced invasion/migration of glioblastoma cells through activating PKCalpha/ERK/NF-kappaB-dependent MMP-9 expression. J Cell Physiol 2010, 225:472-481.

28. Lee J, Ishihara A, Oxford G, Johnson B, Jacobson K: Regulation of cell movement is mediated by stretch-activated calcium channels. Nature 1999, 400:382-386.

29. Ridley AJ, Schwartz MA, Burridge K, Firtel RA, Ginsberg MH, Borisy G, Parsons $J T$, Horwitz AR: Cell migration: integrating signals from front to back. Science 2003, 302:1704-1709.

30. Sjaastad MD, Nelson WJ: Integrin-mediated calcium signaling and regulation of cell adhesion by intracellular calcium. Bioessays 1997, 19:47-55.

31. Schauble N, Lang S, Jung M, Cappel S, Schorr S, Ulucan O, Linxweiler J, Dudek J, Blum R, Helms V, et al: BiP-mediated closing of the Sec61 channel limits $\mathrm{Ca}(2+)$ leakage from the ER. Embo J 2012, 31:3282-3296.

32. Wittke S, Dunnwald M, Johnsson N: Sec62p, a component of the endoplasmic reticulum protein translocation machinery, contains multiple binding sites for the Sec-complex. Mol Biol Cell 2000, 11:3859-3871.

33. Christie RJ, Nishiyama N, Kataoka K: Delivering the code: polyplex carriers for deoxyribonucleic acid and ribonucleic acid interference therapies. Endocrinology 2009, 151:466-473.

34. Jackson AL, Linsley PS: Recognizing and avoiding siRNA off-target effects for target identification and therapeutic application. Nat Rev Drug Discov 2010, 9:57-67.

35. Koehn S, Schaefer HW, Ludwig M, Haag N, Schubert US, Seyfarth L, Imhof D, Markert UR, Poehlmann TG: Cell-specific RNA interference by peptideinhibited-peptidase-activated siRNAs. J RNAi Gene Silencing 2010, 6:422-430.

36. Schmidt C: RNAi momentum fizzles as pharma shifts priorities. Nat Biotechnol 2011, 29:93-94.

37. Bonetta L: RNA-based therapeutics: ready for delivery? Cell 2009, 136:581-584

38. Coticchia CM, Revankar CM, Deb TB, Dickson RB, Johnson MD: Calmodulin modulates Akt activity in human breast cancer cell lines. Breast Cancer Res Treat 2009, 115:545-560.

39. Hwang YP, Jeong HG: Metformin blocks migration and invasion of tumour cells by inhibition of matrix metalloproteinase- 9 activation through a calcium and protein kinase Calpha-dependent pathway: phorbol-12-myristate-13-acetate-induced/extracellular signal-regulated kinase/activator protein-1. Br J Pharmacol 2010, 160:1195-1211.

40. Jung HJ, Kim JH, Shim JS, Kwon HJ: A novel Ca2+/calmodulin antagonist $\mathrm{HBC}$ inhibits angiogenesis and down-regulates hypoxia-inducible factor. J Biol Chem 2010, 285:25867-25874.

41. Yuan K, Jing G, Chen J, Liu H, Zhang K, Li Y, Wu H, McDonald JM, Chen Y: Calmodulin mediates Fas-induced FADD-independent survival signaling in pancreatic cancer cells via activation of Src-extracellular signal-regulated kinase (ERK). J Biol Chem 2011, 286:24776-24784.

42. Polischouk AG, Holgersson A, Zong D, Stenerlow B, Karlsson HL, Moller L, Viktorsson K, Lewensohn R: The antipsychotic drug trifluoperazine inhibits DNA repair and sensitizes non small cell lung carcinoma cells to DNA double-strand break induced cell death. Mol Cancer Ther 2007, 6:2303-2309.

43. Satyamoorthy K, Perchellet JP: Modulation by adriamycin, daunomycin, verapamil, and trifluoperazine of the biochemical processes linked to mouse skin tumor promotion by 12-0-tetradecanoylphorbol-13-acetate. Cancer Res 1989, 49:5364-5370.

44. Carpenter WT Jr, Davis JM: Another view of the history of antipsychotic drug discovery and development. Mol Psychiatry 2012, 17(12):1168-1173.

45. Shen WW: A history of antipsychotic drug development. Compr Psychiatry 1999, 40:407-414.

46. Ghantous A, Gali-Muhtasib H, Vuorela H, Saliba NA, Darwiche N: What made sesquiterpene lactones reach cancer clinical trials? Drug Discov Today 2010, 15:668-678.

47. Christensen SB, Skytte DM, Denmeade SR, Dionne C, Møller JV, Nissen P, Isaacs JT: A Trojan horse in drug development: targeting of thapsigargins towards prostate cancer cells. Anticancer Agents Med Chem 2009, 9:276-294.

48. Huang J-K, Huang C-C, Lu T, Chang H-T, Lin K-L, Tsai J-Y, Liao W-C, Chien J-M, Jan C-R: Effect of MK-886 on $\mathrm{Ca}_{2+}$ level and viability in PC3 human prostate cancer cells. Basic Clin Pharmacol Toxicol 2009, 104:441-447.

49. Denmeade SR, Isaacs JT: The SERCA pump as a therapeutic target: making a "smart bomb" for prostate cancer. Cancer Biol Ther 2005, 4:14-22.

50. Denmeade SR, Mhaka AM, Rosen DM, Brennen WN, Dalrymple S, Dach I, Olesen C, Gurel B, Demarzo AM, Wilding G: Engineering a prostate-specific membrane antigen-activated tumor endothelial cell prodrug for cancer therapy. Sci Transl Med 2012, 4:140ra186.

doi:10.1186/1471-2407-13-574

Cite this article as: Linxweiler et al:: Targeting cell migration and the endoplasmic reticulum stress response with calmodulin antagonists: a clinically tested small molecule phenocopy of SEC62 gene silencing in human tumor cells. BMC Cancer 2013 13:574.

\section{Submit your next manuscript to BioMed Central and take full advantage of:}

- Convenient online submission

- Thorough peer review

- No space constraints or color figure charges

- Immediate publication on acceptance

- Inclusion in PubMed, CAS, Scopus and Google Scholar

- Research which is freely available for redistribution 